\title{
Long-term Measurements of Carbonaceous Aerosol at Cape Hedo, Okinawa, Japan: Effects of Changes in Emissions in East Asia
}

\author{
Kojiro Shimada ${ }^{1,2,9^{*}}$, Akinori Takami ${ }^{3}$, Takatsugu Ishida², Yuta Taniguchi ${ }^{2}$, \\ Shuichi Hasegawa ${ }^{4}$, Chak K. Chan ${ }^{5}$, Yong Pyo Kim ${ }^{1,6,7}$, Neng-Huei Lin ${ }^{1,8}$, \\ Shiro Hatakeyama ${ }^{1,2+}$
}

\author{
${ }^{1}$ Global Innovation Research Organization, Tokyo University of Agriculture and Technology, \\ Tokyo, Japan \\ ${ }^{2}$ Institute of Agriculture, Graduate School of Tokyo University of Agriculture and Technology, \\ Tokyo, Japan \\ ${ }^{3}$ National Institute for Environmental Studies, Onogawa, Tsukuba, Ibaraki, Japan \\ ${ }^{4}$ Center for Environmental Science in Saitama, Kazo, Saitama, Japan \\ ${ }^{5}$ School of Energy and Environment, City University of Hong Kong, Hong Kong, China \\ ${ }^{6}$ Department of Chemical Engineering \& Materials Science, Ewha Womans University, Seoul, \\ Korea \\ ${ }^{7}$ Department of Environmental Science \& Engineering, Ewha Womans University, Seoul, Korea \\ ${ }^{8}$ National Central University, Chung-Li, Taiwan \\ ${ }^{9}$ School of Creative Science and Engineering, Waseda University, Tokyo, Japan
}

Received: August 5, 2020 Revised: April 29, 2021 Accepted: May 6, 2021

\section{${ }^{*}$ Corresponding Author:} kshimada@sci.u-ryukyu.ac.jp; kshimada@cs.u-ryukyu.ac.jp

\section{${ }^{\dagger}$ Present address: Asia Center for Air Pollution Research, Niigata, Japan}

\footnotetext{
₹ Present address: Department of Chemistry, Biology, and Marine Science, University of the Ryukyus, Okinawa 9030213 Japan
}

\section{Publisher:}

Taiwan Association for Aerosol Research

ISSN: $1680-8584$ print

ISSN: 2071-1409 online

\section{Copyright: The Author(s)}

This is an open access article distributed under the terms of the Creative Commons Attribution License (CC BY 4.0), which permits unrestricted use, distribution, and reproduction in any medium, provided the original author and source are cited.

\section{ABSTRACT}

We investigated the changes in the carbonaceous-aerosol sources and their effects on the long-term elemental carbon (EC) and organic carbon (OC) concentration trends at the Cape Hedo Atmosphere and Aerosol Monitoring Station (CHAAMS) in Okinawa, Japan, during the period 20042013. We obtained the EC and OC concentrations by conducting semi-real-time measurements using a carbon monitor, and performing an offline thermal/optical filter analysis according to the Interagency Monitoring of Protected Visual Environments (IMPROVE) protocol. The annual average concentration of the EC remained constant between 2004 and 2013, but that of the OC decreased at a rate of $0.11 \mu \mathrm{g} \mathrm{C} \mathrm{m} \mathrm{y}^{-1}(\alpha>0.05)$. The secondary OC (SOC)/OC ratio showed an increasing trend from 2004 till 2011, which may have been caused by a reduction in primary emissions of $\mathrm{OC}$ and compositional changes in the organic compounds originating in China, from which air pollutants were frequently transported during spring and winter. Although the EC concentration did not change appreciably in either season, the OC concentration decreased at rates of $0.10 \mu \mathrm{g} \mathrm{C} \mathrm{m}^{-3} \mathrm{y}^{-1}$ and $0.11 \mu \mathrm{g} \mathrm{C} \mathrm{m}^{-3} \mathrm{y}^{-1}$ during spring and winter, respectively. We estimated the contributions from the various sources of carbonaceous aerosol, viz., biomass burning, fossil-fuel combustion, and air-pollutant transport from China, based on the OC/EC ratio, which decreased from 5.7 to 2.4 in terms of the annual average. The growing share from fossil-fuel combustion is responsible for the decline in biofuel-burning OC emissions transported from China to CHAAMS.

Keywords: Carbonaceous aerosol, CHAAMS, Fossil fuel combustion, Biomass burning, Long-term trend

\section{INTRODUCTION}

Elemental carbon (EC), or black carbon (BC), is known to cause both warming and degraded air quality. $B C$ is the most critical light-absorbing component in atmospheric aerosols and a contributor to climate change although short-lived compared to other long-lived gases. Air 
pollutants such as BC are called short-lived climate pollutants (SLCPs) (Shindell et al., 2012). BC concentrations have been reported to show a downward trend in Europe (Bower et al., 2009) and the United States (Kirchstetter et al., 2008; Murphy et al., 2011; Hand et al., 2013) but an upward trend in Asia (Ohara et al., 2007). For example, Bower et al. (2009) reported that the BC concentration decreased 1952-2005 in England, and Kirchstetter et al. (2008) reported a decrease 1967-2003 in the ambient BC concentration in San Francisco, California, United States, despite an increase in fuel consumption. These observations were attributed to the successful implementation of technologies controlling BC emissions. In the American and European Arctic region, BC has decreased at Zeppelin, Ny-Ålesund, Alert, Barrow, and Split (Eleftheriadis et al., 2009; Hirdman et al., 2010) due to a downward trend of BC concentrations in United States and Europe. On the other hand, the contribution of $B C$ and sulfate concentrations derived from northern Eurasia including East Asia increase in 1989 to 2009 (Hirdman et al., 2010).

According to Kondo et al. (2011) and Matsui et al. (2011), in the Arctic Research of the Composition of the Troposphere from Aircraft and Satellites (ARCTAS) mission, the amount of BC and sulfate transported from Asia to the Arctic region was found to be higher than that transported from the North America to the Arctic. As one of the reasons, rapid economic development has caused increased energy consumption along with a higher rate of increase in anthropogenic air pollution in Asia (Ohara et al., 2007; Zhang et al., 2009). Estimates of the global and regional effects of air pollutants (such as BC) in Asia on climate change contain large uncertainties. Analyses of the long-term trend in $\mathrm{BC}$ in Asia based on global and regional monitoring are rather scarce.

At the Cape Hedo Atmosphere and Aerosol Monitoring Station (CHAAMS) in Okinawa, Japan, observations of transboundary air pollution have been performed since 2004. CHAAMS has been designated as a major atmosphere-monitoring station by the United Nations Environment Programme in the Asian region (Takami et al., 2007; Nakajima et al., 2008; Shimada et al., 2015). To understand the impact of air pollution on the climate, ecosystems, and human health, we examined the formation of secondary aerosols, such as sulfate and nitrate (Takami et al., 2005, 2007; Takiguchi et al., 2008). In particular, in order to improve the three-dimensional regional model, weinvestigated the process of chemical transformations of these secondary aerosols during longrange transport. We previously studied seasonal variations and source areas of carbonaceous aerosols from 2004 till 2008 in air masses transported from East Asia to CHAAMS (Shimada et al., 2011) as well as identified specific sources within the source area (Shimada et al., 2015). Our longterm observations at CHAAMS from 2004 till 2009 showed that large-scale transboundary airpollution (LSP) events frequently occur in winter (Shimada et al., 2016). In addition, we have compared emission inventories with each of the aforementioned studies to understand carbonaceous-aerosol sources and emissions in China. Studying the long-term trends in OC and EC concentrations also supplies information for improving three-dimensional regional model in East Asia. Therefore, in this study, by investigating the long-term trends of OC and EC concentrations, we focus on the relationship between the long-term trends in $O C$ and EC concentrations over CHAAMS and examine the relation between these trends and emission changes in China.

\section{EXPERIMENTAL METHOD}

CHAAMS $\left(26.87^{\circ} \mathrm{N}, 128.25^{\circ} \mathrm{E}, 60 \mathrm{~m}\right.$ above sea level) is located at the northern end of Okinawa Island in Japan. The site is approximately $100 \mathrm{~km}$ from Naha, which is the largest city on the island, and approximately $650 \mathrm{~km}$ from Shanghai in a straight line, one of the major cities in China. There is no major industrial or residential activity around the station. Air masses reaching CHAAMS are primarily transported from China, Korea, Japan, Southeast Asia, and the Pacific Ocean; therefore, this site is suitable for observing the long-range transport characteristics of air pollutants in East Asia (Takami et al., 2007).

The $\mathrm{OC}$ and EC concentrations in aerosols were measured using an ambient-carbon monitor (Series 5400; Rupprecht \& Patashnick Co., Inc. [R\&P], Albany, New York, USA) at 3-h intervals from March 2004 till May 2011. OC concentration and total carbon (TC) concentration were analyzed with a non-dispersive infrared $\mathrm{CO}_{2}$ sensor on the basis of desorption at $350^{\circ} \mathrm{C}$ and $750^{\circ} \mathrm{C}$, respectively. $\mathrm{EC}$ concentration was calculated as the difference between TC concentration and OC concentration (Shimada et al., 2016). 
In addition to the aforementioned continuous measurements, carbonaceous aerosol was collected on quartz filters (Shimada et al., 2011) and analyzed using a thermal/optical carbon analyzer (Model 2001; Desert Research Institute [DRI], Reno, Nevada, USA), following the Interagency Monitoring of Protected Visual Environments (IMPROVE) protocol (Chow et al., 2001). Aerosol particles for analyses of $O C$ and $E C$ in $P_{2} M_{2.5}$ were collected on quartz-microfiber filters with a diameter of $47 \mathrm{~mm}$ (Pallflex Tissuquartz 2500QAT-UP; Pall Corp., East Hills, New York, USA) using an Federal Reference. Method 2025 apparatus (Thermo Electron Corp., Franklin, Massachusetts, USA) operated at a flow rate of $16.7 \mathrm{~L} \mathrm{~min}^{-1}$. None of the quartz fiber filters were baked before sampling because the amount of volatile organic compounds (VOCs) adsorbed onto unbaked quartz fiber filters is lower than the amount adsorbed onto baked $\left(900^{\circ} \mathrm{C}\right)$ quartz fiber filters (Hasegawa, 2014). Three categories of blank filters were used: field (at the rate of 4 filters per month), travel ( 6 filters per month), and laboratory (4 filters per month) (Shimada et al., 2015). The detection limits of $O C$ and $E C$ were 0.90 and $0.10 \mu \mathrm{g} \mathrm{m}^{-3}$, respectively. The OC and EC samples were collected on a weekly basis from March 2010 till March 2014, but they were intensively sampled on a daily (24-h) basis during spring (March-May) in 2010 and 2011.

Because the Rupprecht and Patashnick [R\&P] Series 5400 (RP5400) carbon monitors are known to have low collection efficiency and high time resolution $(3 \mathrm{~h})$, the concentrations measured by this thermal method were scaled using methods developed by U.S. EPA (2001), Green et al. (2007) and Quincey et al. (2009) with a semi-continuous EC and OC field analyzer (Sunset Laboratory Inc., Oregon, USA). The measurement principle of Sunset Laboratory instruments is similar to DRI instrument (thermal/optical method). Applying a thermal/optical method, both studies compared Sunset Laboratory instruments in the field with RP5400 instruments using the data observed at roadsides in England. Their conversion equation was $E C_{(R P 5400)}=(0.22 \pm 0.02) E C_{(\text {sunset })}$ $+(0.88 \pm 0.26)(N=92)$. In our case, the conversion coefficient was calculated by comparing the daily measured raw data obtained from the DRI instrument with the data acquired from the R\&P instrument for the periods from March till May of 2010 and 2011 (Shimada et al., 2016). The conversion equation for $\mathrm{OC}$ is:

$Y_{(D R I)}=(2.3 \pm 0.23) X_{(R P 5400)}+(0.11 \pm 0.10)$

and that for TC is:

$Y_{(D R I)}=(2.3 \pm 0.18) X_{(R P 5400)}+(0.16 \pm 0.1)$

where $X$ is the concentration obtained using RP5400. As mentioned, EC was calculated as TC OC (Shimada et al., 2016).

Water-soluble organic carbon (WSOC) concentration in $\mathrm{PM}_{2.5}$ was analyzed with DRI instrument. The analysis of WSOC concentration was performed in the same manner as for OC and EC concentrations. Five punches of $0.5 \mathrm{~cm}^{2}$ were taken from sample filters, and then, WSOC contained in these filters was extracted with ultra-pure water. The extracted solution was absorbed in a heat-treated $0.5-\mathrm{cm}^{2}$ filter. After the filter was dried by infrared light, WSOC concentration was analyzed by DRI instrument.

At CHAAMS, we also measured polycyclic aromatic hydrocarbons (PAHs) contained in filtered aerosol samples collected from 2004 till 2013. Concentrations of retene, one of the molecular markers of biomass burning, were measured. Methods for sampling and analyzing retene were described by Miura et al. (2019). We used the same data in Sato et al. (2007b), Sato et al. (2008), Yoshino et al. (2011), Ogawa et al. (2012) and Miura et al. (2019). The sampling periods and number of samples used in the current study are shown in Table S1. Furthermore, the durations of the seasons were considered to be as follows: March-May for spring, June-August for summer, September-November for autumn, and December-February for winter.

\section{RESULTS AND DISCUSSION}

\subsection{Trends in OC and EC Concentrations from 2004 till 2013}

Fig. 1 shows the monthly trends in OC and EC concentrations from 2004 till 2013. The 
(a)

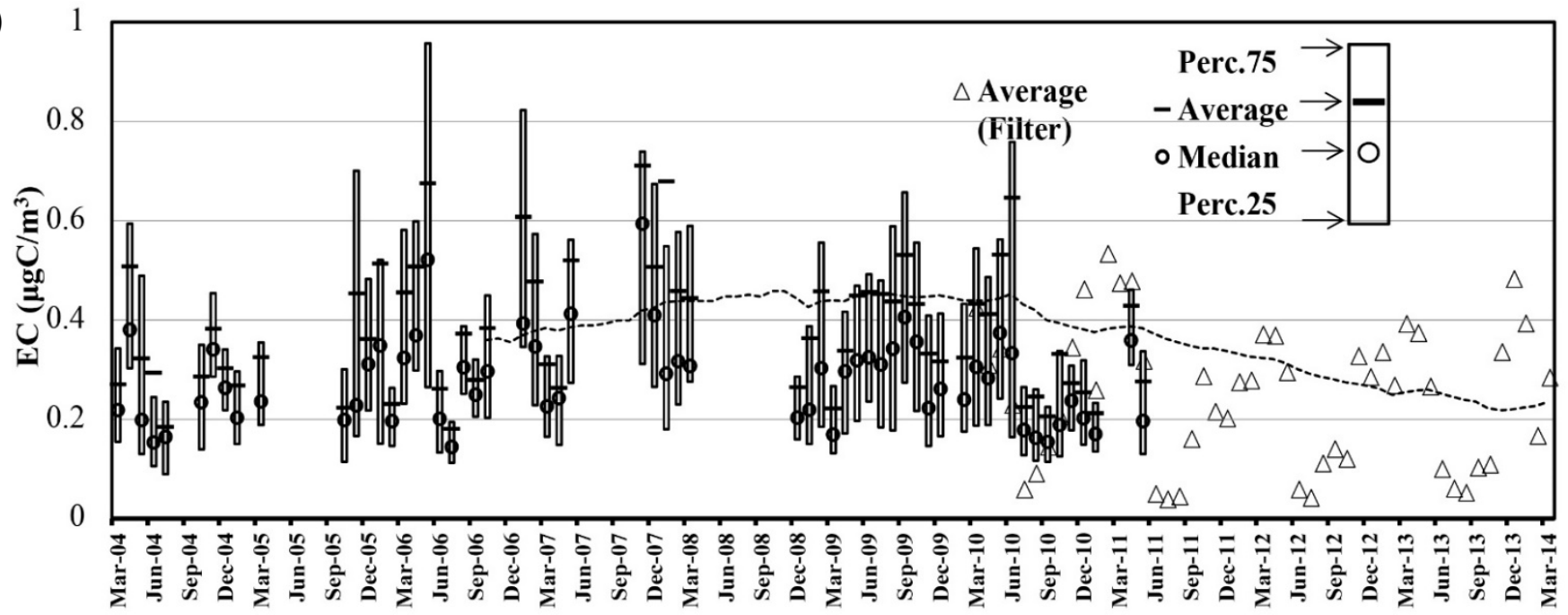

Month

(b)

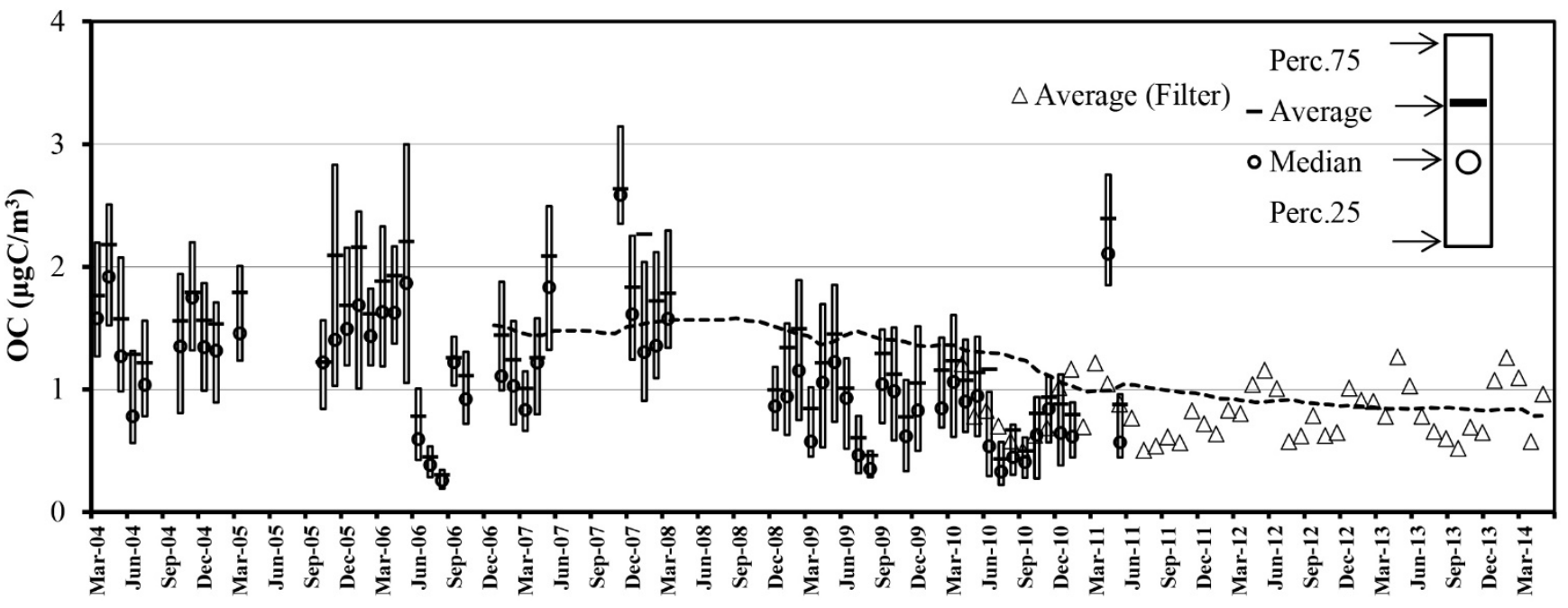

Month

Fig. 1. The trends in monthly concentrations of (a) EC and (b) OC from 2004 till 2014. The dashed line represents a 3-y running mean of monthly averages. The solid bars and circles represent monthly means and median concentrations in box-and-whisker plot (same hereinafter).

concentrations were high in spring and winter, typically because of aerosols transported from China. In our previous studies, we reported high concentrations of $\mathrm{PM}_{2.5}, \mathrm{OC}, \mathrm{EC}, \mathrm{CO}, \mathrm{O}_{3}$, and major ionic components in rainwater during spring and winter and low concentrations during summer at CHAAMS (Shimada et al., 2011). In addition, metallic and ionic species in $\mathrm{PM}_{2.5}$ were all high during spring and winter but low during summer (Shimada et al., 2015). The flow of air masses is governed by the wind field, created by pressure gradients as shown in Miura et al. (2019) in which the seasonal mean wind fields from 2008 to 2015 are shown. In winter, spring and fall, a high-pressure system is often located over northwestern China and a low-pressure over the western Pacific Ocean. On the other hand, in summer, a high-pressure system is often located over the western Pacific Ocean. Therefore, air pollutants were mainly transported from China during spring and winter. The $\mathrm{OC}$ and EC data for summer were insufficient for a detailed analysis to examine the relation between OC and EC trends and emission changes in China, and therefore, we excluded summer data.

As exhibited in Fig. 2, the annual average and median concentrations of EC did not show any significant increase in the period 2004-2014. By contrast, the annual average and median 
(a)

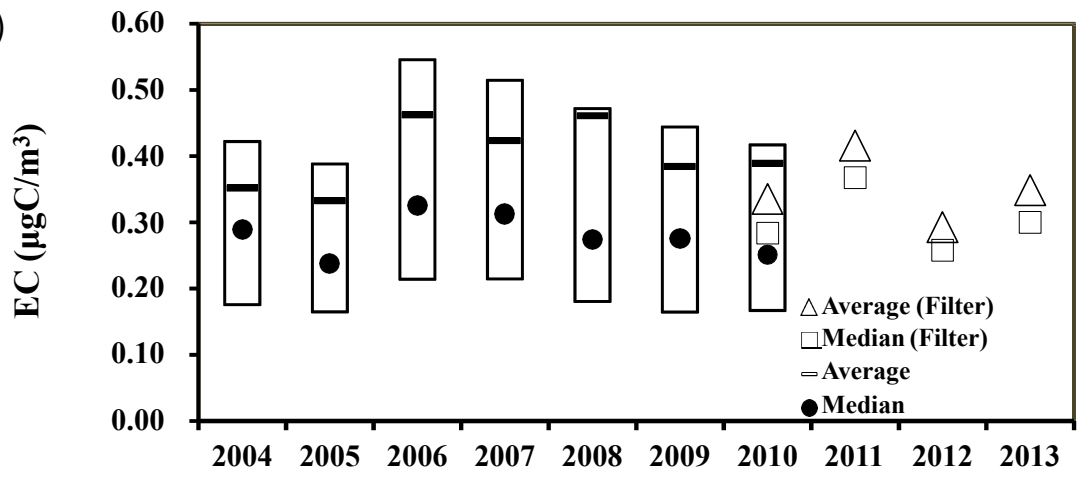

(b)

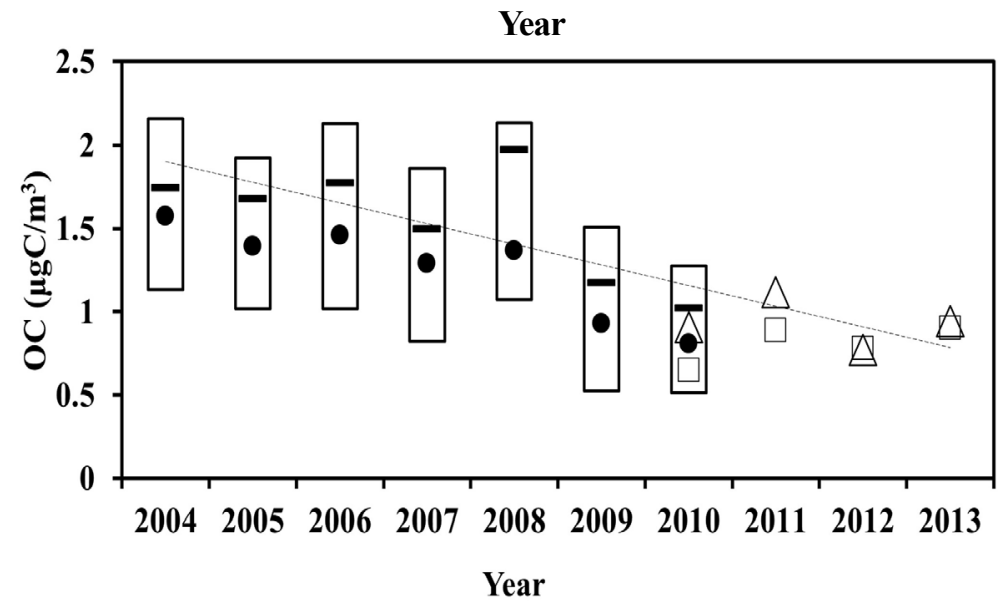

Fig. 2. The annual trends of (a) EC and (b) OC concentrations from 2004 till 2013, excluding summer data. $\mathrm{OC}_{\text {(average) }}: Y=-0.1 X+1.7(\alpha>0.05, R=0.64) ; \mathrm{OC}_{\text {(median) }}: Y=-0.1 X+2.0(\alpha>0.05, R$ $=0.84)$.

concentrations of OC clearly decreased at the rate of $0.12 \mu \mathrm{g} \mathrm{C} \mathrm{m}^{-3} \mathrm{y}^{-1}\left(7 \% \mathrm{y}^{-1} ; R=0.73, \alpha>0.05\right.$ when 2004 is considered the base year) and $0.10 \mu \mathrm{g} \mathrm{C} \mathrm{m}^{-3} \mathrm{y}^{-1}\left(7 \% \mathrm{y}^{-1} ; R=0.83\right)$, respectively.

The average EC concentrations are typically higher than the median concentrations. Furthermore, the difference between the average and the median concentrations increases at higher concentrations. Several major episodes increased the average EC concentrations in spring and winter. We observed LSP events in winter. The OC and EC concentrations were highest in month of the year when LSP persisted over the CHAAMS 4-6 daysin winter (Shimada et al., 2016). Although these observations indicate the importance of episodic events to EC, the difference between average and median values is less pronounced than that for OC (Fig. 1), indicating that the aforementioned episodes affect EC concentration more than OC concentration, even though the latter is higher. To investigate the influence of episodic events on average and median EC concentrations, we analyzed the increase-decrease rates of the annual trends in OC and EC concentrations. Fig. S2 shows the frequency distributions of the quantity (average median)/median for EC concentration and OC concentration, and Fig. 2 shows the annual trends in OC and EC concentrations from 2004 till 2013. The frequency of EC concentration is predominantly higher than that of $\mathrm{OC}$ concentration, and the quantity (average - median)/median for EC concentration varies between $20 \%$ and $70 \%$. It was found that the above episodes affect EC concentration rather than OC concentration. Although LSP might influence the annual trend in EC, it does not affect the annual trend in OC.

Fig. 3 shows the annual trends in EC and OC in spring and winter, when air pollutants were frequently transported from China to Japan. The average and median EC concentrations did not show appreciable changes (Figs. 3 and S1), whereas the average and median OC concentrations showed a considerable decrease in both winter and spring. Episodes such as those of LSP did not affect the average and median OC concentrations (Fig. S2), which decreased at the rate of $0.10 \mu \mathrm{g} \mathrm{C} \mathrm{m}^{-3} \mathrm{y}^{-1}\left(5 \% \mathrm{y}^{-1}\right)$ in spring and $0.11 \mu \mathrm{g} \mathrm{C} \mathrm{m}^{-3} \mathrm{y}^{-1}\left(7 \% \mathrm{y}^{-1}\right)$ in winter (Figs. 3 and S1). We 


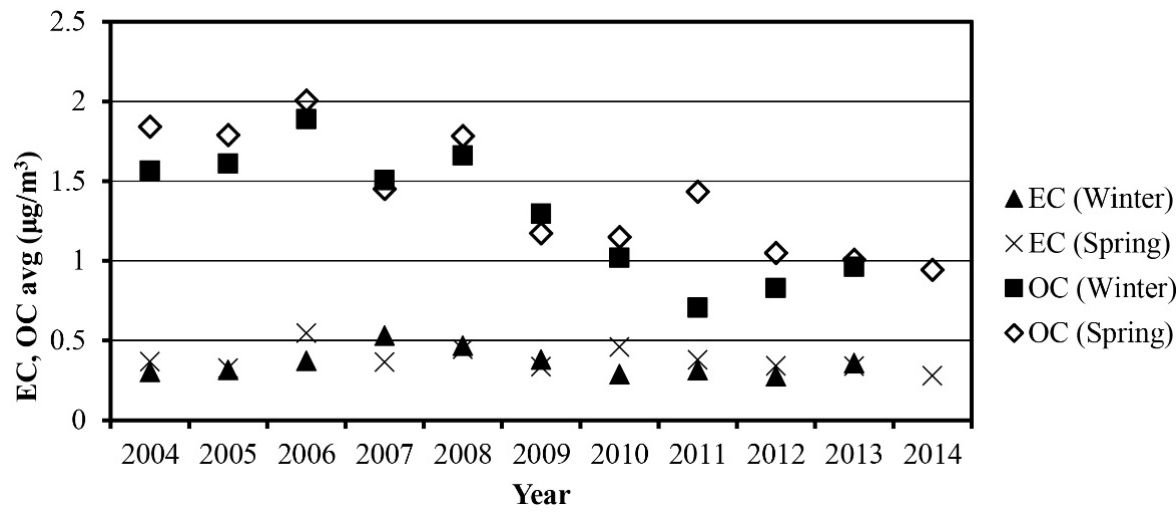

Fig. 3. The annual trends of average (a) EC and (b) OC concentrations in spring and winter from 2004 till 2014. OC (spring): $Y=-0.1 X+1.9(\alpha>0.05, R=0.64) ; \mathrm{OC}_{\text {(winter) }}: Y=-0.1 X+1.9(\alpha>0.05, R$ $=0.76)$.

checked for trends by applying the Mann-Kendall test, which is widely used to verify the significance of tendencies in data sets (Miura et al., 2019). No significant increasing or decreasing trends in EC $(P>0.05)$ were found in any given season over the study period. On the other hand, decreasing trends in OC $(P<0.05)$ were found in spring and winter. The decreasing trend from winter through spring observed at CHAAMS may indicate a reduction in OC emissions in China from the past decade.

\subsection{Annual Trends in POC and SOC from 2004 till 2013}

Primary emissions of $\mathrm{OC}$ are expected to have decreased over the past decade. Here, we examined the secondary formation of OC using the EC-tracer method. According to Turpin and Huntzicker (1991), the contributions of primary organic carbon (POC) and secondary organic carbon (SOC) concentrations can be estimated as:

$C_{\mathrm{POC}}=E C \times(O C / E C)_{\min }$

$C_{\mathrm{SOC}}=O C-C_{\mathrm{POC}}$

where $(O C / E C)_{\min }$ is the observed minimum $O C / E C$ ratio. The $(O C / E C)_{\min }$ values were determined by using the RP5400 data for spring and winter and taking the average of the 10 minimum OC/EC ratios (Turpin and Huntzicker, 1995) for the period 2004-2010. The obtained values were 2.91 $\left(R^{2}=0.99\right), 2.95\left(R^{2}=0.85\right), 1.78\left(R^{2}=0.99\right), 0.98\left(R^{2}=0.84\right), 1.57\left(R^{2}=0.84\right), 0.64\left(R^{2}=0.74\right)$, and $0.67\left(R^{2}=0.90\right)$ for $2004,2005,2006,2007,2008,2009$, and 2010, respectively. Moreover, for the filtered samples collected in 2010 and 2011, (OC/EC $)_{\min }$ was determined as the average value of the two lowest OC/EC ratios in these years. We used OC and EC data from the spring of 2010 and 2011, when intensive daily sampling was conducted throughout the season. The $(O C / E C)_{\min }$ values for 2010 and 2011 were $0.95\left(R^{2}=0.83\right)$ and $1.17\left(R^{2}=0.98\right)$, respectively. Because the samples with the minimum OC/EC ratios at CHAAMS might contain SOC, the contribution of SOC could be underestimated by the EC-tracer method. Zhang et al. (2008) reported that $(O C / E C)_{\min }$ ranged from 0.9 to 2.4 at 18 stations of the China Atmosphere Watch Network (CAWNET) in China in 2006. In our study, the SOC/OC ratio increased from 2004 till 2007 and thereafter stabilized (Fig. 4). It is noteworthy that the use of yearly $(O C / E C)_{\min }$ from 2010 to 2013 instead of average $(O C / E C)_{\min }$ would only lead to a larger increase in the SOC/OC ratio. This is because SOC/OC data from filter sampling were used for spring of 2010 and 2013. The annual trends of the SOC/OC ratio from 2004 till 2010, excluding summer data from 2004 till 2010, was used from the RP5400 data. For reference, we showed SOC/OC ratios from 2010 till 2013 using the calculated average $(O C / E C)_{\min }$ values (1.06) based on 2010 and 2011 data. These ratios were consistently higher $(\sim 75 \%)$ in rural areas due to reduced contributions of primary OC concentrations.

Moreover, in the current study, the relationship between SOC and WSOC concentrations was found to be $Y=0.70 X+0.32(R=0.62)$ (Fig. S3). Here, $X$ is the estimated SOC concentration, and 


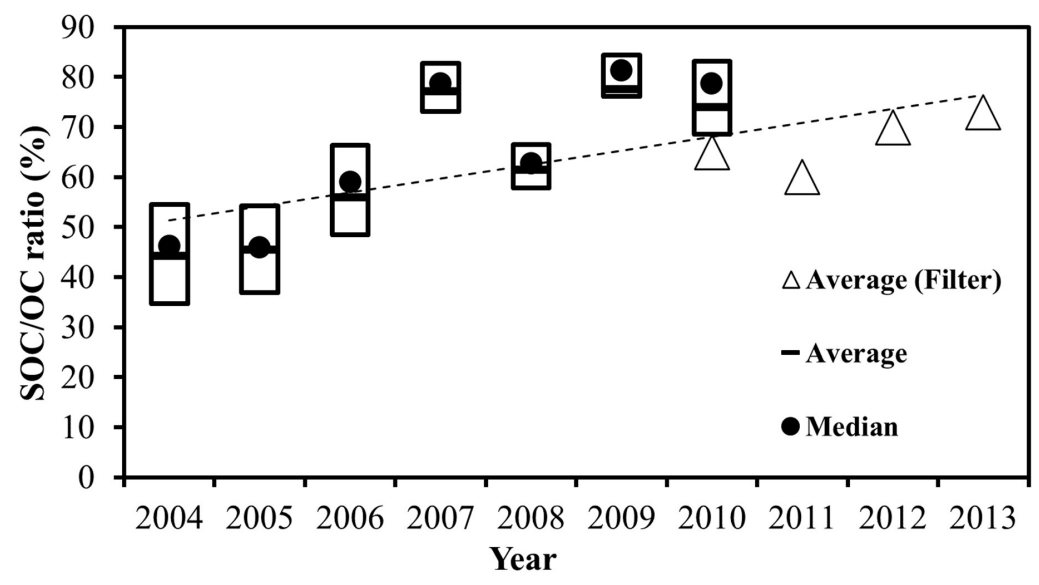

Fig. 4. The annual trends of the SOC/OC ratio from 2004 till 2010, excluding summer data from 2004 till 2010, from RP5400 measurements. SOC/OC data from filter sampling were used for spring of 2010 and 2013. SOC/OC: $Y=2.8 X+48.7(\alpha>0.05, R=0.67)$.

$Y$ is the measured WSOC concentration. When SOC is produced by a photochemical oxidation reaction as shown below, the main component of SOC is water-soluble. Therefore, SOC and WSOC are highly correlated (Miyazaki et al., 2006). SOC concentration is known to be formed from gas-phase photo-oxidation of VOCs, such as isoprene (Kroll et al., 2006) and monoterpenes (Hatakeyama et al., 1989), and aromatic compounds (Sato et al., 2007a) as well as carbonyl and semi-volatile organic species from anthropogenic emissions (Hatakeyama et al., 1994; Robinson et al., 2007) formed through oxidation by ozone or radicals such as $\mathrm{OH}$ and $\mathrm{NO}_{3}$.

The trend in ozone concentration at CHAAMS from 2001 till 2013 did not show either upward or downward trends (Kato et al., 2014), and therefore, the high SOC content in OC was not due to an increase in the ozone concentration. Huang et al. (2015) reported that based on the OC/EC ratios in literature, SOC is increasing in urban Shanghai. Thence, they discussed the contribution of VOC emissions, such as those with high aromatic contents, to secondary organic aerosol (SOA) formation and the relative importance of vehicular emissions. They suggested that gasoline exhaust is an important factor in SOA formation based on the relative contributions of gasoline and diesel vehicles to vehicle-origin organic aerosol. Kurokawa et al. (2013) reported that emissions from solvent and paint increased rapidly to $38 \%$ in 2008 , exceeding those from road transport (35\%). Zheng et al. (2017) also reported that solvent emissions are estimated to have increased by $52 \%$ since 2010 . Toluene and $\mathrm{C}_{8}$ aromatics were the most abundant species, accounting for $76 \%$ of the total VOCs emitted from paint applications (Yuan et al., 2010). De Smedt et al. (2010) reported that an upward trend of formaldehyde-column abundance was observed over northeastern China $\left(4 \% \mathrm{y}^{-1}\right)$ based on data retrieved from the Global Ozone Monitoring Experiment (GOME) and Scanning Imaging Absorption Spectrometer for Atmospheric Chartography (SCIAMACHY) instruments between 1997 and 2009. Formaldehyde is one of the important intermediate products from the oxidation of VOCs. They also reported that the detected trend in formaldehyde-column abundance could be explained by changes in the emissions of corresponding anthropogenic non-methane hydrocarbon (NMHC), which were reported by Ohara et al. (2007). The trend of formaldehyde can mainly be used as an indicator of tropospheric VOC emissions. It seems that the SOC/OC ratio is increasing at the rate of $2.7 \% \mathrm{y}^{-1}$ due to the reduction of $\mathrm{OC}$ emission and the change in composition of $\mathrm{OC}$ in China.

\subsection{OC/EC Ratio and Retene as a Molecular Marker of Biomass Burning}

Fig. 5 shows the annual trend in the OC/EC ratio from 2004 till 2013. This ratio is useful for examining the relative importance of sources of carbonaceous aerosols, namely biomass burning and fossil-fuel combustion. The OC/EC ratios of the products of coal combustion, oil combustion, and vehicle emissions, and biomass burning have been suggested to be 3.0 and 12.3 , respectively (Bond et al., 2004; Cao et al., 2005), indicating the greater importance of biomass burning. The annual average OC/EC ratio decreased from 5.7 to 2.4 , at the rate of $0.28 \mathrm{y}^{-1}\left(5 \% \mathrm{y}^{-1} ; R=0.66\right.$, 


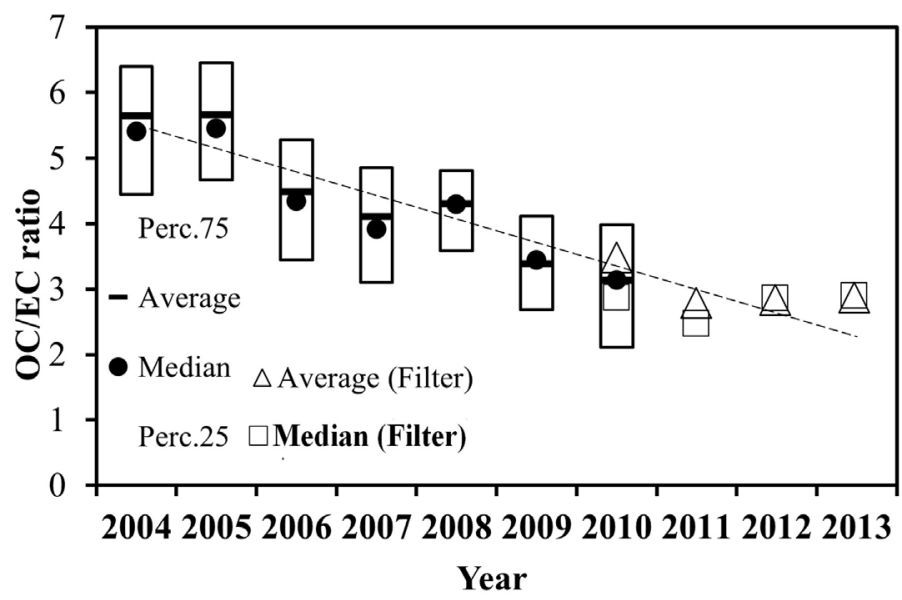

Fig. 5. The annual trends of OC/EC ratios from 2004 till 2013, excluding summer data. OC/EC: $Y=$ $-0.28 X+5.5(\alpha>0.05, R=0.66)$.

$\alpha>0.05$, with 2004 as the base year). The yearly trend in OC/EC ratios for spring and winter from 2004 till 2013 showed an appreciable decrease (Fig. S4) at the rate of $0.26 y^{-1}\left(4 \% y^{-1}\right)$ in spring and $0.28 \mathrm{y}^{-1}\left(5 \% \mathrm{y}^{-1}\right)$ in winter. According to the Mann-Kendall test, decreasing trends in OC/EC ratio $(P<0.05)$ were found in spring and winter over the study period, suggesting that the contribution of fossil-fuel combustion increase more than biomass burning to carbonaceous aerosols. Our results agree with the results of Kim et al. (2011), who reported a decrease in the OC/EC ratio at Gosan, Korea, from 1992 till 2008. Handa et al. (2010) reported that ${ }^{14} \mathrm{C} /{ }^{12} \mathrm{C}$ analysis of the EC indicated a greater contribution from fossil-fuel combustion $(\sim 60 \%)$ than biomass burning ( 40\%). When low EC concentrations were observed, ${ }^{14} \mathrm{C} /{ }^{12} \mathrm{C}$ analysis of $\mathrm{OC}$ indicated that the contribution of fossil-fuel combustion ( 40\%) was less than that of biomass burning ( 60\%). The contribution of OC probably does not reflect biomass burning; rather, this increase may have been caused by SOA derived from biogenic VOCs (Handa et al., 2010).

Moreover, the OC/EC ratios in the air masses that originated in North China and South China were $1.98 \pm 0.05$ and $2.83 \pm 0.03$, respectively, using the same data from 2004 to 2008 (Shimada et al., 2011). OC/EC ratios estimated for North China and South China based on the Asian emission inventory data set were 1-2 and 2-3, respectively (Shimada et al., 2011). Thus, our observational data are in accordance with the emission inventory data. The low OC/EC ratios (< 3 ) in both North China and South China indicate that the sources of the EC and OC were anthropogenic (Shimada et al., 2011). In order to identify specific source categories for EC and OC using the same data in the air masses from China and Korea, we used Positive Matrix Factorization-Potential Source Contribution Function (PMF-PSCF) analysis results (Shimada et al., 2015), which provided information on air-mass transport. While oil combustion occurred in South China, coal combustion occurred in North China, with high contributions from the former in spring and the latter in winter (Shimada et al., 2015).

The yearly trend in the OC/EC ratio indicates that the contribution to carbonaceous aerosols from biomass burning has decreased at CHAAMS. We also compare the yearly trend in the OC/EC ratio with emission inventories in Section 3.4.

The website of the Acid Deposition Monitoring Network in East Asia (EANET; led by the Ministry of the Environment, Japan) reported the monthly trends of potassium concentration in $\mathrm{PM}_{10}$ during spring and winter at Cape Hedo from 2004 till 2012 (http://www.eanet.asia/). The main sources of potassium are biomass burning and sea salt. The non-sea-salt potassium (nss-potassium) concentration, obtained from the $\mathrm{Na}^{+}$concentration, first increased from 2004 and then decreased, showing a slight overall decrease during the aforementioned period (Fig. 6). At Gosan, it slightly decreased overall from 1992 till 2008 (Kim et al., 2011). The trend at CHAAMS from 2004 till 2008 is in agreement with the observations made at Gosan. Overall, the trend in the potassium concentration supports the observed decrease in the contribution of biomass burning to ambient aerosols. However, due to low potassium concentration, PMF analysis did not show the contribution from biomass burning (Shimada et al., 2015). 


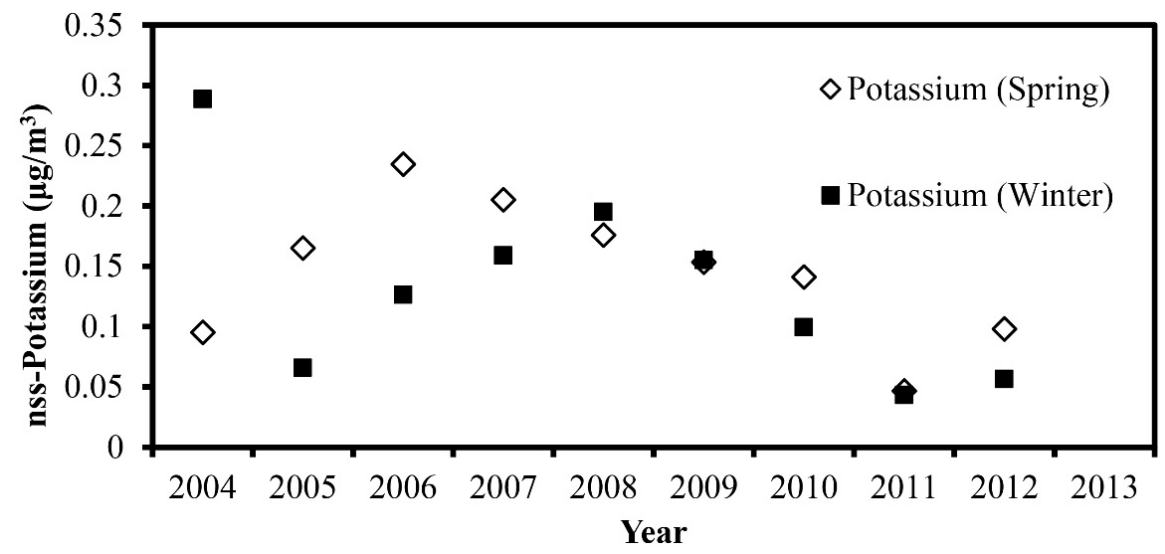

Fig. 6. The annual trends of non-sea-salt potassium concentrations in spring and winter from 2004 till 2013.

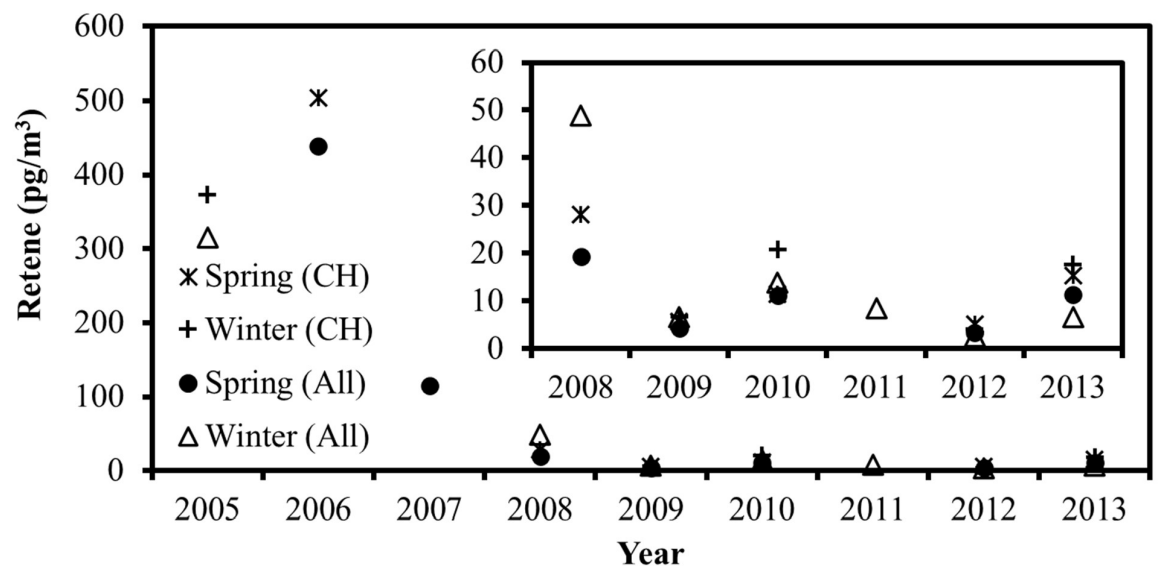

Fig. 7. The annual trends of retene concentrations in spring and winter from 2004 till 2013. CH means the fraction of air-mass origins from the area including part of China.

Levoglucosan has often been used as a marker of biomass burning (Simoneit et al., 2002). However, recent findings have reported that its lifetime is rather short, up to $12 \mathrm{~h}$, because of rapid photochemical oxidation in the droplet phase (Teraji et al., 2010) and that it may not be suitable for use as a marker in humid environments. Retene concentration is another marker of biomass burning, especially softwood burning (Ramdahl, 1983; McDonald et al., 2000; Fine et al., 2001; Simoneit, 2002). We monitored retene, a persistent organic pollutant, to examine changes in the biomass-burning source strength. Fig. 7 shows the annual average concentrations of retene in spring and winter from 2004 till 2013. Fig. 7 also shows the annual average concentrations of retene transported from China classified by back-trajectory analysis. Table S2 shows sampling periods and sample number from 2005 to 2013. PAH concentrations at CHAAMS in each season were dominated by PAHs transported from China. PAH concentrations were highest in winter and lowest in spring (Miura et al., 2019; Shimada et al., 2020). We used the data classified as of Chinese origin by back trajectory in these references (Sato et al., 2007b, 2008; Yoshino et al., 2011; Ogawa et al., 2012; Miura et al., 2019). Retene concentrations transported from China dominate the long-term trend of Cape Hedo. In other words, the retene concentrations transported from China determine the long-term trends of retene.

During this period, the retene concentration based on all data sets decreased from $315 \mathrm{pg} \mathrm{m}^{-3}$ to $7 \mathrm{pg} \mathrm{m}^{-3}$ (in winter) and from $439 \mathrm{pg} \mathrm{m}^{-3}$ to $11 \mathrm{pg} \mathrm{m}^{-3}$ (in spring), indicating a decrease in the contribution from biomass burning to carbonaceous aerosols.

Examining the OC/EC ratio, nss-potassium concentration, and retene concentration, we found that the contribution from biomass burning to carbonaceous aerosols has decreased at CHAAMS. 


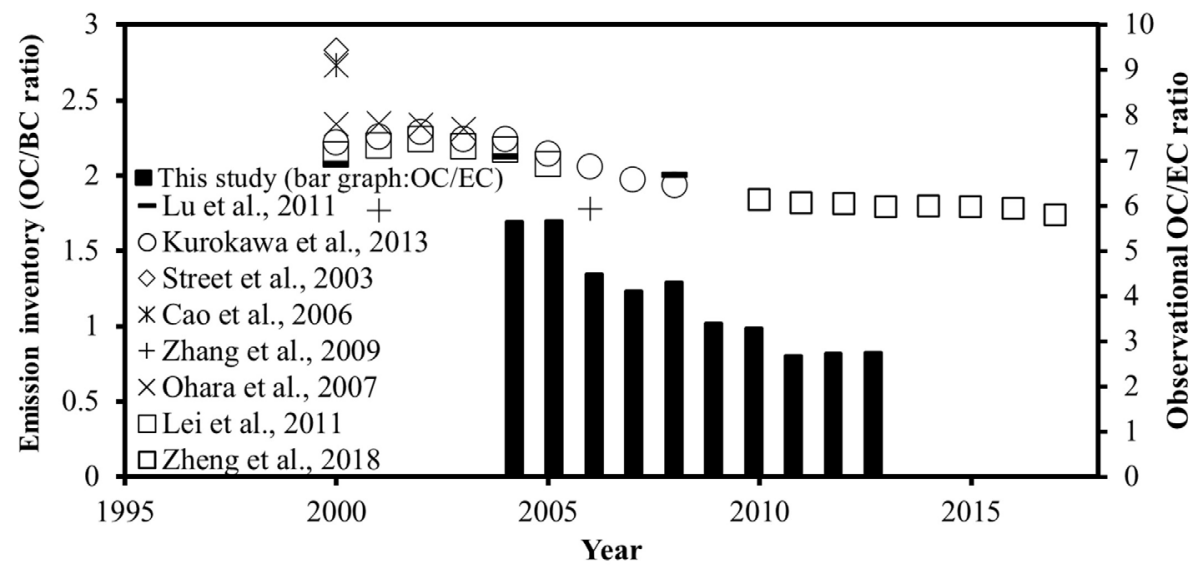

Fig. 8. Comparison of OC/BC emission inventories from China based on references (left axis) with observed OC/EC concentrations (bar graph) at CHAAMS in this study (right axis).

\subsection{Comparison of the Annual Trends in OC and EC with Emission Inventories}

The annual trends in the OC and EC concentrations at CHAAMS from 2004 till 2008 and 2010 to 2017 were also quite consistent with changes in the emission inventories in China reported by Kurokawa et al. (2013) and Zheng et al. (2018). The annual trend in the OC/BC ratio in emissions in China decreased during this period, consistent with the decrease in the OC/EC ratio at CHAAMS (Fig. 8). Carbonaceous aerosol emissions in China originate mainly from residential biofuel and coal combustion. According to the Regional Emission Inventory in Asia (REAS; version 2.1; Kurokawa et al., 2013) and Multi-resolution Emission Inventory for China (MEIC; Zheng et al., 2018), due to a reduction in biofuel consumption in China, BC emissions have increased since 2000, and OC emissions have decreased since 2006. Kurokawa et al. (2013) and Zheng et al. (2018) reported that more than half of the total BC emissions in China during 2000 were from the domestic sector (e.g., biofuel consumption). BC emissions from this sector have decreased since 2006, and industrial emissions reached levels equal to domestic emissions in 2008 (with each category contributing approximately $45 \%$ to the total BC emissions). The road-transport sector has become more important, with a share of $11 \%$ (Kurokawa et al., 2013). Kurokawa et al. (2013) reported that OC emissions decreased by $16 \%$ between 2006 and 2008.

It is noteworthy that Kurokawa et al. (2013) and Zheng et al. (2018) considered biofuel consumption such as wood burning but not open biomass burning in the emission inventory. Lu et al. (2010) described the overall trend in the annual change in emissions from open biomass burning in China from 2004 till 2010 on the basis of the Global Fire Emissions Database (GFED; version 3.1), reporting that $\mathrm{OC}$ emissions from open biomass burning of forests and savannas vary from year to year. The emissions are largely dependent on the amount of precipitation and soil moisture. Although the emission factor is highly uncertain, OC emissions from this source type account for $2-11 \%$ of the total emissions in China, depending on the year. Li et al. (2009) reported that the $\mathrm{OC}$ emission factor varies in the range $0.85-3.97 \mathrm{~g} \mathrm{~kg}^{-1}$ among different types of biofuels. OC emission also depends on the moisture content of biomass fuels (Venkataraman et al., 2005). In a laboratory experiment, OC emission factors of fuelwood were observed to be approximately $0.4 \mathrm{~g} \mathrm{~kg}^{-1}$ at low burn rates and as high as $2.7 \mathrm{~g} \mathrm{~kg}^{-1}$ at high burn rates (Venkataraman et al., 2005). In general, the contribution of open burning to OC emissions is considered low. Therefore, we believe that a decrease in biofuel consumption in China caused the decreasing trend in OC concentration observed at CHAAMS. The annual trend in the OC/EC ratio at CHAAMS, and the trend in the OC/BC ratio in emissions in the study by Kurokawa et al. (2013) and Zheng et al. (2018) (Fig. 8) consistently show the large contribution of fossil-fuel combustion to carbonaceous aerosols at CHAAMS.

\section{CONCLUSION}

This study assessed the levels of the carbonaceous aerosols at Cape Hedo from 2004 till 2014. 
Using an ambient-carbon-particulate monitor, we measured the $\mathrm{OC}$ and $\mathrm{EC}$ concentrations in these aerosols every $3 \mathrm{~h}$ between March 2004 and May 2011. Additionally, following the IMPROVE protocol, we collected samples of the carbonaceous aerosols on quartz filters between March 2010 and March 2014 and quantified the carbon content with a DRI Model 2001 thermal/optical carbon analyzer.

The annual EC concentration exhibited a stable trend from 2004 till 2014. However, both the annual average and median $\mathrm{OC}$ concentrations decreased at a rate of $0.10 \mu \mathrm{g} \mathrm{C} \mathrm{m} \mathrm{y}^{-1}$ during this period owing to the reduction in OC emissions in China over the past decade. Specifically,

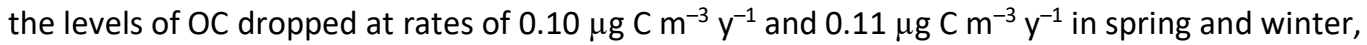
respectively, during which air pollution from China frequently arrived in Japan.

The annual average of the OC/EC ratio, which can be used to estimate the contributions of biomass burning and fossil-fuel combustion to carbonaceous aerosols, decreased from 5.7 in 2004 to 2.4 in 2014, or at a rate of $0.28 \mathrm{y}^{-1}$, indicating a reduction in the relative contribution of biomass burning. Comparing the $\mathrm{BC}$ to the $\mathrm{OC}$ emission-inventory data in REAS v.2.1 and MEIC, we found that the declining $\mathrm{OC}$ concentrations observed at CHAAMS can be attributed to the remarkable decrease in biofuel consumption in China.

\section{ACKNOWLEDGMENTS}

This study was partly supported by a Grant-in-Aid for Scientific Research in Innovative Areas (No. 4003, Impacts of Aerosols in East Asia on Plants and Human Health) from the Ministry of Education, Culture, Sports, Science and Technology, Japan, by a Sasagawa Scientific Research Grant from the Japan Science Society, and by the Global Environment Research Fund of the Japanese Ministry of the Environment (2-1403).

\section{SUPPLEMENTARY MATERIAL}

Supplementary material for this article can be found in the online version at https://doi. org/10.4209/aaqr.200505

\section{REFERENCES}

Bond, T.C., Streets, D.G., Yarber, K.F., Nelson, S.M., Woo, J.H., Klimont, Z. (2004). A technologybased global inventory of black and organic carbon emissions from combustion. J. Geophys. Res. 109, D14203 https://doi.org/10.1029/2003JD003697

Bower, S.A., Susan, M.L., Stefan, F.G., Claus, W.B. (2009). Interior pathways of the North Atlantic meridional overturning circulation. Nature 459, 243-247. https://doi.org/10.1038/nature07979

Cao, G.L., Zhang, X.Y., Zheng, F.C. (2006). Inventory of black carbon and organic carbon emissions from China. Atmos. Environ. 40, 6516-6527. https://doi.org/10.1016/j.atmosenv.2006.05.070

Chow, J.C, Watson, J.G, Crow, D., Lowenthal, D.H., Merrifield, T. (2001). Comparison of IMPROVE and NIOSH carbon measurements. Aerosol Sci. Technol. 34, 23-34. https://doi.org/10.1080/02786 820119073

De Smedt, I., Stavrakou, T., Müller, J.F., van der A, R.J., Van Roozendael, M. (2010). Trend detection in satellite observations of formaldehyde tropospheric columns. Geophys. Res. Lett. 37, L18808. https://doi.org/10.1029/2010GL044245

Eleftheriadis, K., Vratolis, S., Nyeki, S. (2009). Aerosol black carbon in the European Arctic: Measurements at Zeppelin station, Ny-Ålesund, Svalbard from 1998-2007. Geophys. Res. Lett. 36, L02809. https://doi.org/10.1029/2008GL035741

Fine, P.M., Cass, G.R., Simoneit, B.R.T. (2001). Chemical characterization of fine particle emissions from fireplace combustion of woods grown in the northeastern United States. Environ. Sci. Technol. 35, 2665. https://doi.org/10.1021/es001466k

Green, D., Alexander, J., Fuller, G., Quincey, P., Butterfield, D. (2007). Marylebone Road Aethalometer Trial Report. UK-AIR: Air Information. https://uk-air.defra.gov.uk/assets/docum ents/reports/cat13/0711261353_Marylebone_Road_Aethalometer_Trial.pdf 
Hand, J.L., Schichtel, B.A., Malm, W.C., Frank, N.H. (2013). Spatial and temporal trends in PM2.5 organic and elemental carbon across the United States. Adv. Meteorol. 2013, 367674. https://doi.org/10.1155/2013/367674

Hatakeyama, S., Akimoto, H. (1994). Reactions of Criegee intermediates in the gas phase. Res. Chem. Intermed. 20, 503-524. https://doi.org/10.1163/156856794X00432

Hatakeyama, S., Izumi, K., Fukuyama, T., Akimoto, H. (1989). Reactions of ozone with $\alpha$-pinene and e pinene in air: Yields of gaseous and particulate products. J. Geophys. Res. 94, 1301313024. https://doi.org/10.1029/JD094iD10p13013

Hirdman, D., Burkhart, F.J., Sodemann, H., Eckhardt, S., Jefferson, A., Quinn, K.P., Sharma, S. Strom, J., Stohl, A. (2010). Long-term trends of black carbon and sulphate aerosol in the Arctic: Changes in atmospheric transport and source region emissions. Atmos. Chem. Phys. 10, 12133-12184. https://doi.org/10.5194/acp-10-9351-2010

Huang, C., Wang, H.L., Li, L., Wang, Q., Lu, Q., de Gouw, J.A., Zhou, M., Jing, S.A., Lu, J., Chen, C.H. (2015). VOC species and emission inventory from vehicles and their SOA formation potentials estimation in Shanghai, China. Atmos. Chem. Phys. 15, 11081-11096. https://doi.org/10.5194/ac p-15-11081-2015

Kato, S., Jeeranut, S., Kajii, Y., Shiroma, T., Iwasaki, A., Kadena, H., Tomoyose, N., Toguchi, T. (2014). Long term observation of $\mathrm{CO}, \mathrm{O}_{3}, \mathrm{VOC}$ at cape Hedo, Okinawa. $55^{\text {th }}$ Annual meeting of the Japan Society for Atmospheric Environment, Japan. (in Japanese)

Kim, N.K., Kim, P.Y., Kang, C.H. (2011). Long-term trend of aerosol composition and direct radiative forcing due to aerosols over Gosan: TSP, $\mathrm{PM}_{10}$, and $\mathrm{PM}_{2.5}$ data between 1992 and 2008. Atmos. Environ. 45, 6107-6115. https://doi.org/10.1016/j.atmosenv.2011.08.051

Kirchstetter, T.W., Aguiar, J., Tonse, S., Fairley, D., Novakov, T. (2008). Black carbon concentrations and diesel vehicle emission factors derived from coefficient of haze measurements in California: 1967-2003. Atmos. Environ. 42, 480-491. https://doi.org/10.1016/j.atmosenv.2007.09.063

Kondo, Y., Matsui, H., Moteki, N., Sahu, L., Takegawa, N., Kajino, M., Zhao, Y., Cubison, J.M. Jimenez, L.J., Vay, S., Diskin, S.G., Anderson, B., Wisthaler, A., Mikoviny, T., Fuelberg, E.H., Blake, R.D., Huey, G., Weinheimer, J.A., Knapp, J.D., Brune, H.W. (2011). Emissions of black carbon, organic, and inorganic aerosols from biomass burning in North America and Asia in 2008. J. Geophys. Res. 116, D08204. https://doi.org/10.1029/2010JD015152

Kroll, J.H., Ng, N.L., Murphy, S.M., Flagan, R.C., Seinfeld, J.H. (2006). Secondary organic aerosol formation from isoprene photooxidation. Environ. Sci. Technol. 40, 1869-1877. https://doi.org/ 10.1021/es0524301

Kurokawa, J., Ohara, T., Morikawa, T., Hanayama, S., Janssens-Maenhout, G., Fukui, T., Kawashima, K., Akimoto, H. (2013). Emissions of air pollutants and greenhouse gases over Asian regions during 2000-2008: Regional Emission inventory in ASia (REAS) version 2. Atmos. Chem. Phys. 13, 11019-11058. https://doi.org/10.5194/acp-13-11019-2013

Lei, Y., Zhang, Q., He, K.B., Streets, D.G. (2011). Primary anthropogenic aerosol emission trends for China, 1990-2005. Atmos. Chem. Phys. 11, 931-954. https://doi.org/10.5194/acp-11-931-2011

Lu, Z., Streets, G.D., Zhang, Q., Wang, S., Carmichael, R.G., Cheng, F.Y., Wei, C., Chin, M., Diehl, T., Tan, Q. (2010). Sulfur dioxide emissions in China and sulfur trends in East Asia since 2000. Atmos. Chem. Phys. 10, 6311-6331. https://doi.org/10.5194/acp-10-6311-2010

Lu, Z., Zhang, Q., Streets, D.G. (2011). Sulfur dioxide and primary carbonaceous aerosol emissions in China and India, 1996-2010. Atmos. Chem. Phys. 11, 9839-9864. https://doi.org/10.5194/a cp-11-9839-2011

Matsui, H., Kondo, Y., Moteki. N., Takegawa, N., Sahu, K.L., Zhao, Y., Fuelberg, E., Sessions, R.W., Diskin, G., Blake, R.D., Wisthaler, A., Koike, M. (2011). Seasonal variation of the transport of black carbon aerosol from the Asian continent to the Arctic during the ARCTAS aircraft campaign. J. Geophys. Res. 116, D05202. https://doi.org/10.1029/2010JD015067

McDonald, J.D., Zielinska, B., Fujita, E.M., Sagebiel, J.C., Chow, J.C., Watson, J.G., (2000). Fine particle and gaseous emission rates from residential wood combustion. Environ. Sci. Technol. 34, 2080-2091. https://doi.org/10.1021/es9909632

Miura, K., Shimada, K., Sugiyama, T., Sato, K., Takami, A., Chan, C.K., Kim, I.S., Kim, Y.P., Lin, N.H., Hatakeyama, S., (2019). Seasonal and annual changes in PAH concentrations in a remote site in the Pacific Ocean. Sci. Rep. 9, 12591. https://doi.org/10.1038/s41598-019-47409-9

Miyazaki, Y., Kondo, Y., Takegawa, N., Komazaki, Y., Fukuda, M., Kawamura, K., Mochida M. 
Okuzawa K., Weber, R.J. (2006). Time-resolved measurements of water-soluble organic carbon in Tokyo. J. Geophys. Res., 111, D23206. https://doi.org/10.1029/2006JD007125

Murphy, D.M., Chow, J.C., Leibensperger, E.M., Malm, W.C., Pitchford, M., Schichtel, B.A., Watson, J.G., White, W.H. (2011). Decreases in elemental carbon and fine particle mass in the United States. Atmos. Chem. Phys. 11, 4679-4686. https://doi.org/10.5194/acp-11-4679-2011

Nakajima, T., Yoon, C.S., Ramanathan, V., Shi, Y.G., Takemura, T., Higurashi, A., Takamura, T., Aoki, K., Sohn, J.B., Kim, W.S., Tsuruta, H., Sugimoto, N., Shimizu, A., Tanimoto, H., Sawa, Y., Lin, H.N., Lee, T.C., Goto, D., Schutgens, N. (2007). Overview of the Atmospheric Brown Cloud East Asian Regional Experiment 2005 and a study of the aerosol direct radiative forcing in east Asia. J. Geophys. Res., 112, D24S91. https://doi.org/10.1029/2007JD009009

Ogawa, Y., Kaneyasu, N., Sato, K., Takami, A., Hayashi, M., Hara, K., Hatakeyama, S. (2012). PAHs and n-Alkanes transported long-range. J. Jpn. Soc. Atmos. Environ.47, 18-25. https://doi.org/ 10.11298/taiki.47.18

Ohara, T., Akimoto, H., Kurokawa, J., Horii, N., Yamaji, K., Yan, X., Hayasaka, T. (2007). An Asian emission inventory of anthropogenic emission sources for the period of 1980-2020. Atmos. Chem. Phys. 7, 4419-4444. https://doi.org/10.5194/acp-7-4419-2007

Quincey, P., Butterfield, D., Green, D., Coyle, M., Cape, N.J. (2009). An evaluation of measurement methods for organic, elemental and black carbon in ambient air monitoring sites. Atmos. Environ. 43, 5085-5091. https://doi.org/10.1016/j.atmosenv.2009.06.041

Ramana, M.V., Ramanathan, V., Feng, Y., Yoon, C.S., Kim, W.S., Carmichael, R.G., Schauer, J.J. (2010). Warming influenced by the ratio of black carbon to sulphate and the black-carbon source. Nat. Geosci. 3, 542-545. https://doi.org/10.1038/ngeo918

Ramdahl, T. (1983). Retene - A molecular marker of wood combustion in ambient air. Nature 306, 580-582. https://doi.org/10.1038/306580a0

Robinson, A.L., Donahue, N.M., Shrivastava, M.K., Weitkamp, E.A., Sage, A.M., Grieshop, A.P., Lane, T.E., Pierce, J.R., Pandis, S.N. (2007). Rethinking organic aerosols: Semivolatile emissions and photochemical aging. Science 315, 1259-1262. https://doi.org/10.1126/science.1133061

Sato, K., Hatakeyama, S., Imamura, T. (2007a). Secondary organic aerosol formation during the photooxidation of toluene: $\mathrm{NO}_{\mathrm{x}}$ dependence of chemical composition. J. Phys. Chem. A 111, 9796-9808. https://doi.org/10.1021/jp071419f

Sato, K., Tanaka, Y., Li, H., Ogawa, S., Hatakeyama, S. (2007b). Distributions and seasonal changes of organic aerosols at Cape Hedo, Okinawa: Polycyclic aromatic hydrocarbons observed during 2005-2006. Chikyukagaku 41, 145-153. https://doi.org/10.14934/chikyukagaku.41.145 (in Japanese)

Sato, K., Li, H., Tanaka, Y., Ogawa, S., Iwasaki, Y., Takami, A., Hatakeyama, S. (2008). Long-range transport of particulate polycyclic aromatic hydrocarbons at Cape Hedo remote island site in the East China Sea between 2005 and 2008. J. Atmos. Chem. 61, 243-257. https://doi.org/10. 1007/s10874-009-9135-4

Shimada, K., Takami, A., Kato, S., Yoshizumi, K., Hatakeyama, S. (2011). Variation of carbonaceous aerosol in polluted air mass transported from East Asia and evaluation of their source origin. J. Jpn. Soc. Atmos. Environ. 46, 1-9. https://doi.org/10.11298/taiki.46.1 (in Japanese)

Shimada, K., Shimada, M., Takami, A., Hasegawa, S., Fushimi, A., Arakaki, T., Watanabe, I., Hatakeyama, S. (2015). Mode and place of origin of carbonaceous aerosols transported from east Asia to Cape Hedo, Okinawa, Japan. Aero. Air Quality Res. 15, 799-813. https://doi.org/1 0.4209/aaqr.2014.09.0190

Shimada, K, Takami, A., Kato, S., Yoshizumi, K., Hasegawa, S., Fushimi, A., Shimizu, A., Sugimoto, N., Chan, K.C., Kim, P.Y., Lin, H.N., Hatakeyama, S. (2016). Characteristics of carbonaceous aerosols in large-scale Asian wintertime outflows at Cape Hedo, Okinawa, Japan. J. Aerosol Sci. 100, 97-107. https://doi.org/10.1016/j.jaerosci.2016.05.006

Shimada, K., Nohchi, M., Yang, X., Sugiyama, T., Miura, K., Takami, A., Sato, K., Chen, X., Kato, S. Kajii, Y., Meng, F., Hatakeyama, S, (2020). Degradation of PAHs during long range transport based on simultaneous measurements at Tuoji Island, China, and at Fukue Island and Cape Hedo, Japan, Environ. Pollut, 260, 113906. https://doi.org/10.1016/j.envpol.2019.113906

Shindell, D., Kuylenstierna, J.C., Vignati, E., van Dingenen, R., Amann, M., Klimont, Z., Anenberg, S.C., Muller, N., Janssens-Maenhout, G., Raes, F., Schwartz, J., Faluvegi, G., Pozzoli, L., Kupiainen, K., Hoglund-Isaksson, L., Emberson, L., Streets, D., Ramanathan, V., Hicks, K., Oanh, N.T., Milly, 
G., et al. (2012). Simultaneously mitigating near-term climate change and improving human health and food security. Science 335, 183-189. https://doi.org/10.1126/science.1210026

Simoneit, B.R.T. (2002). Biomass burning-A review of organic tracers for smoke from incomplete combustion. Appl. Geochem. 17, 129-162. https://doi.org/10.1016/S0883-2927(01)00061-0

Streets, D.G., Bond, T.C., Carmichael, G.R., Fernandes, S.D., Fu, Q., He, D., Klimont, Z., Nelson, S.M., Tsai, N.Y., Wang, M.Q., Woo, J.H., Yarber, K.F. (2003). An inventory of 20 gaseous and primary aerosol emissions in Asia in the year 2000. J. Geophys. Res. 108, 8809. https://doi.org/10.1029/2002JD003093

Takami, A., Miyoshi, T., Shimono, A., Hatakeyama, S. (2005). Chemical composition of fine aerosol measured by AMS at Fukue Island, Japan during APEX priod. Atmos. Environ. 39, 4913-4924. https://doi.org/10.1016/j.atmosenv.2005.04.038

Takami, A., Miyoshi, T., Shimono, A., Kaneyasu, N., Kato, S., Kajii, Y., Hatakeyama, S. (2007) Transport of anthropogenic aerosols from Asia and subsequent chemical transformation. J. Geophys. Res. 112, D22S31. https://doi.org/10.1029/2006JD008120

Takiguchi, Y., Takami, A., Sadanaga, Y., Lun, X., Shimizu, A., Matsui, I., Sugimoto, N., Wang, W. Bandow, H., Hatakeyama, S. (2008). Transport and transformation of total reactive nitrogen over the East China Sea. J. Geophys. Res. 113, D10306. https://doi.org/10.1029/2007JD009462

Teraji, T., Arakaki, T. (2010). Bimolecular rate constants between levoglucosan and hydroxyl radical: Effects of $\mathrm{pH}$ and temperature. Chem. Lett. 39, 900-901. https://doi.org/10.1246/cl.2 010.900

Turpin, B.J., Huntzicker, J.J. (1995). Identification of secondary organic aerosol episodes and quantitation of primary and secondary organic aerosol concentrations during SCAQS. Atmos. Environ. 29, 3527-3544. https://doi.org/10.1016/1352-2310(94)00276-Q

U.S. Environmental Protection Agency (U.S. EPA) (2001). Environmental Technology Verification Report - ETV Advanced Monitoring Systems Center - Rupprecht \& Patashnick, Co. Series 5400 Ambient Particulate Carbon Monitor. U.S. Environmental Protection Agency. https://archive.e pa.gov/nrmrl/archive-etv/web/pdf/01_vr_rupp_5400c.pdf

Venkataraman, C., Habib, G., Eiguren-Fernandez, A., Miguel, A.H., Fiedlander, S.K. (2005). Residential biofuels in South Asia: Carbonaceous aerosols emissions and climate impacts. Science 307, 1454-1456. https://doi.org/10.1126/science.1104359

Verma, R.L., Kondo, Y., Oshima, N., Matsui, H., Kita, K., Sahu, L.K., Kato, S., Kajii, Y., Takami, A., Miyakawa, T. (2011). Seasonal variations of the transport of black carbon and carbon monoxide from the Asian continent to the western Pacific in the boundary layer. J. Geophys. Res. 116, D21307. https://doi.org/10.1029/2011JD015830

Weber, R.J., Sullivan, A.P., Peltier, R.E., Russell, A., Yan, B., Zheng, M., de Gouw, J., Warneke, C., Brock, C., Holloway, J.S., Atlas, E.L., Edgerton, E. (2007). A study of secondary organic aerosol formation in the anthropogenic influenced southeastern United States. J. Geophys. Res. 112, D1330. https://doi.org/10.1029/2007JD008408

Yoshino, A., Nakayama, H., Ogawa, Y., Sato, K., Takami, A., Hatakeyama, S. (2011). Long-Range transport of polycyclic aromatic hydrocarbons from east Asia at Cape Hedo in 2010. Earozoru Kenkyu 26, 307-314. https://doi.org/10.11203/jar.26.307 (in Japanese)

Yuan, B., Shao, M., Lu, S.H., Wang, B. (2010). Source profiles of volatile organic compounds associated with solvent use in Beijing, China. Atmos. Environ. 44, 1919-1926. https://doi.org/ 10.1016/j.atmosenv.2010.02.014

Zhang, X.Y., Wang, Y.Q., Zhang, X.C., Guo, W., Gong, S.L. (2008). Carbonaceous aerosol composition over various regions of China during 2006. J. Geophys. Res. 113, D14111. https://doi.org/10.1029/2007JD009525

Zhang, X., Streets, G.D., Carmichael, R.G., He, B.K., Huo, H., Kannari, A., Klimont, Z., Park, S.I., Reddy, S., Fu, S.J., Chen, D., Duan, L., Lei, Y., Wang, T.L., Yao, L.Z. (2009). Asian emissions in 2006 for the NASA INTEX-B mission. Atmos. Chem. Phys. 9, 5131-5153. https://doi.org/10.519 4/acp-9-5131-2009

Zheng, B., Tong, D., Li, M., Liu, F., Hong, C., Geng, G., Li, H., Li, X., Peng, L., Qi, J., Yan, L., Zhang, Y., Zhao, H., Zheng, Y., He, K., Zhang, Q. (2018). Trends in China's anthropogenic emissions since 2010 as the consequence of clean air actions. Atmos. Chem. Phys. 18, 14095-14111. https://doi.org/10.5194/acp-18-14095-2018 